Discussion Paper No. 627

THE PRODUCTIVITY OF PUBLIC CAPITAL:
EVIDENCE FROM
THE 1994 ELECTORAL REFORM OF JAPAN

\author{
Daiji Kawaguchi \\ Fumio Ohtake \\ Keiko Tamada
}

February 2005

The Institute of Social and Economic Research Osaka University

6-1 Mihogaoka, Ibaraki, Osaka 567-0047, Japan 


\title{
The Productivity of Public Capital: Evidence from the 1994 Electoral Reform of Japan ${ }^{1}$
}

\author{
Daiji Kawaguchi ${ }^{2}$ \\ Fumio Ohtake ${ }^{3}$ \\ Keiko Tamada ${ }^{4}$
}

January 2005

\footnotetext{
${ }^{1}$ We thank Hisahiro Naito and Facundo Sepulveda for their stimulating discussions.

${ }^{2}$ Graduate School of Humanities and Social Sciences, University of Tsukuba, 1-1-1 Tennodai, Tsukuba, Ibaraki 305-8573 Japan; E-mail: kawaguch@sk.tsukuba.ac.jp

${ }^{3}$ Institute of Social and Economic Research, Osaka University, 6-1 Mihogaoka, Ibaraki 567-0047 Osaka, Japan; E-mail: ohtake@iser.osaka-u.ac.jp

${ }^{4}$ Faculty of Economics, Fukuoka University, Nanakuma 8-19-1, Jonan, Fukuoka 814-0180 Japan; E-Mail: ktamada@econ.fukuoka-u.ac.jp
} 


\begin{abstract}
This paper attempts to estimate the causal effect of public capital stock on production using Japanese prefectural data. We first articulate the difficulty of consistently estimating the regional-level production function with public capital due to the endogeneity of the public capital stock amount. As the central government allocates most of the public capital across regions in Japan, the stock amount of public capital could be endogenous because it could be allocated to either booming regions to support private activity or to stagnating regions to help them become more productive. The endogeneity of public capital is more serious when local governments make decisions regarding public capital investments, as in the US, because such decisions are directly affected by local governments' budgetary constraints.

We need an exogenous variation of public capital investment across regions in order to estimate the causal effect of public capital on production. Japan's electoral reform in 1994 offers an exogenous variation of this sort. The reform drastically changed the distribution of political representation in the Lower House across regions, and it accordingly changed the allocation of public capital across regions as well. The productivity of public capital based on this natural experimental identification strategy indicates higher productivity due to public capital than indicated by the OLS estimation. JEL Classification: C25
\end{abstract}

Key Words: Public Capital, Productivity, Political Economy, Instrumental Variable Estimation. 


\section{Introduction}

Estimates of the productivity of public capital, such as highway, port, water, and sewer systems, are crucial in public policy debates. As of fiscal year 1996 in Japan, about 8 trillion yen has been spent on public investment annually, while the total government budget has been about 82 trillion yen and the GNP has been about 500 trillion. Whether this expenditure can be justified heavily depends on the estimated productivity of public capital.

To facilitate public policy debates, economists have attempted to estimate the productivity of public capital. For example, Aschauer (1989), Munnell (1990), Garcia-Mila and McGuire (1992), Holz-Eakin (1994), Evans and Karras (1994), and Garcia-Mila, McGuire, and Porter (1996) have attempted to estimate the public capital productivity for the US. Mera (1973), Asako, Tsuneki, Fukuda, Teruyama, Tsukamoto, and Sugiura (1994), The Economic Planning Agency (1997), Iwamoto, Ouchi, Takeshita, and Bessho (1996), and Yamano and Ohkawara (2000) did the same for Japan. Identifying the causal effect of public capital on national or regional production is difficult, however, because the invested amount in public capital is not randomly decided and is likely to be correlated with a nation's or region's economic condition. Thus, the stock amount of public capital is most likely to be endogenous in the production function. Previous studies have attempted to deal with this endogeneity using panel data, but not much variation in public capital stock remains after partialing out the regional and time fixed effects, and 
this small, remaining variation makes a precise inference very difficult.

The purpose of this study is to identify the causal effect of public capital stock on production, using a recent electoral reform in Japan as a natural experiment that created an exogenous variation of public capital across regions. The drastic electoral reform of Japan in 1994 changed the regional allocation of both political influence and public capital drastically. We exploit this exogenous change in public capital allocation to estimate the productivity of public capital. The estimation results indicate that public capital is modestly productive and suggests a possible downward bias in the OLS estimation that does not consider the endogeneity of the public capital allocation. A reliable instrumental variable fixed effects estimation is hampered by possible measurement errors in input amounts.

The rest of this paper is organized as follows. Section 2 reviews the existing literature and introduces the Japanese political economy of public capital allocation and the 1994 electoral reform, and its effect on public capital allocation. Section 3 discusses the empirical methodology, and section 4 describes the data. Section 5 reports the estimation results, and section 6 discusses the results' robustness. The last section concludes.

\section{Background}

\subsection{The Existing Literature}

The estimation of the marginal productivity of public capital in the US was spurred by Aschauer (1989)'s work, which pointed out that lower produc- 
tivity growth in the US during the 1970s is mostly explained by reduced investment in public capital during that period. Munnell (1990) also reported similar findings. Their studies both were based on macro time-series, and some economists criticized their findings, pointing to the possible endogeneity of public capital because the public capital investment could have been hampered by low tax revenue due in the stagnated economy during the 1970s. Garcia-Mila and McGuire (1992) also found a significant effect of public capital on states' output based on state-level panel data. However, Holz-Eakin (1994) and Evans and Karras (1994) cast doubt on the results because such data do not allow for state fixed effects. After allowing for state fixed effects, they did not find any significant effect of states' public capital on states' output. Garcia-Mila, McGuire, and Porter (1996) also provided a skeptical view on the causal relationship between public capital stock and production, applying a fixed effects estimation on the first-differenced data using state panel data. Studies have indicated that allowing for state fixed effects is important because those states with persistently high levels of production are more likely to hold higher levels of public capital. This is a natural consequence of the fact that state-level public capital is likely to be financed through states' tax revenue in the US. Due to this local government budget constraint, the OLS estimates are likely to suffer from an upward bias. After a decade-long dispute, US economists seem to have reached an agreement that the state public capital does not positively affect state pro- 
duction. ${ }^{1}$ However, it should be noted that there is not much variation in labor, private capital, and public capital input after state and year fixed effects are partialed out (Ai and Cassou (1997)). ${ }^{2}$.

The estimation of the production function with public capital has attracted economists' interest for a longer time in Japan than in the US, probably because public capital is centrally allocated by the national government and the allocation of public capital had been used as a crucial policy instrument to attain "balanced growth" across regions. Mera (1973) estimated the regional production function that includes labor, capital, as well as public capital, as inputs. Since his classic work, numerous studies have attempted to estimate the causal effect of public capital stock on production using prefectural data (Asako, Tsuneki, Fukuda, Teruyama, Tsukamoto, and Sugiura (1994), Mitsui and Ohta (1995), The Economic Planning Agency (1997)). For example, Yamano and Ohkawara (2000) estimated the production function with prefecture fixed effects without year fixed effects, and the elasticity of public capital on production was estimated to be 0.15 with statistical significance. However, in our calculation with prefecture and year fixed effects based on their data, the significantly positive effect disappears. ${ }^{3}$ The regres-

\footnotetext{
${ }^{1}$ Some studies have paid attention to the fact that public capital could affect different sectors in different ways. See Holtz-Eakin and Lovely (1996) for theory and evidence and Chandra and Thompson (2000) for the effect of the interstate highway system on the different sectors of a regional economy.

${ }^{2} \mathrm{Ai}$ and Cassou (1997) regressed public capital stock on state and year dummies and obtained $R^{2}=0.996$ using Holz-Eakin (1994)'s data. They found similar results for the data of Evans and Karras (1994).

${ }^{3}$ We thank Norihiko Yamano and Toru Ohkawara for providing us with their data.
} 
sion of public capital on time and prefecture dummies renders $R^{2}=0.994$. This fact by no means implies that Yamano and Ohkawara (2000)'s conclusion was wrong, but it is worth noting that once both year and prefecture fixed effects are taken into account, empirical studies using Japanese data also suffer from the multicolinearity between public capital and state and year dummies, as articulated by Ai and Cassou (1997).

The above literature review shows the typical robustness-efficiency trade off that empirical economists face. Researchers can deal with the correlation between state (prefecture) unobserved heterogeneity and the stock level of public capital by using a fixed effects estimation; however, the variation of public capital within a state over time is small. Accordingly, the fixed effects estimation tends to render imprecise estimates. Thus, to execute a precise estimation, it is necessary to exploit the variation of public capital across regions due to the exogenous shock by the instrumental variable estimation.

\subsection{The Political Economy of Public Capital Alloca- tion in Japan and the 1994 Electoral Reform}

The electoral reform of Japan in 1994 offers an ideal ground to obtain acrossprefecture exogenous variations of public capital. The electoral reform caused a drastic change in the distribution of each prefecture's political representation in the House of Representatives (Lower House), and, accordingly, it changed the allocation of public capital investment across prefectures due to pork-barrel politics, as already pointed out by Horiuchi and Saito (2003) in 
the form of the allocation of subsidies from the central government to local governments. Because subsidies often are tied to public capital investment, we can expect that the electoral reform created an exogeneous variation of public capital amounts across prefectures. We use this exogeneous variation as an instrumental variable to identify the causal effect of public capital on prefecture production.

In Japan, the central government provides most of the funds for public capital and allocates it across regions. Although government bureaucrats draft the fiscal budget plan, politics are involved in the public capital allocation decision-making process. ${ }^{4}$ Okuno (1988), Okuno, Yakita, and Yagi (1994) and Yoshino and Yoshida (1988) have shown that the central government mostly has allocated the public capital to rural, less developed areas in order to attain the goal of "balanced growth" across regions after the mid 1960s. One major reason why rural areas have attracted more public capital investment per capita than urban areas is the malapportionment of electoral districts in Japan. Under the electoral system that was used before the 1994 reform, the number of the seats in the House of Representatives based on the population had been higher in rural areas because the seat allocation had been relatively fixed while Japan experienced urbanization after World War II. ${ }^{5}$ Yoshino and Yoshida (1988) showed that the number of seats per popu-

\footnotetext{
${ }^{4}$ For a description of the process of how the Japanese government drafts the fiscal budget plan, see Ishi (1996). For evidence of political intervention in the budget's allocation, see Meyer and Naka (1998).

${ }^{5}$ See Horiuchi and Saito (2003) for evidence.
} 
lation positively affected the amount of public capital intended for industrial purposes that each region received. Meyer and Naka (1999) showed that the per capita representation of each prefecture determines the amount of subsidy transfer from the central government to the local government. Horiuchi and Saito (2003) used the more detailed municipal data to show the positive and significant relationship between the seats per capita and the amount of subsidy transfer.

We used the 1994 electoral reform in Japan that conducted drastic reapportionment as a natural experiment. ${ }^{6}$ The reform applied to the election system of the House of Representatives (Lower House), while the electoral system for the House of Councilors (Upper House) stayed constant. Before the reform, all 500 members of the House of Representatives were elected by a single, non-transferable vote system with multi-member districts. After the reform, 300 members were elected by the single-member district (SMD) plurality rule, and another 200 members were elected by the proportional representation (PR) system. For the SMD part, a single seat is allocated to each of the 47 prefecture and the rest are allocated according to the size of the prefecture population. For the PR part, seats are allocated to 11 blocks proportional to the population of each bloc. The first Lower House election after the reapportionment occurred in October 1996.

The change of seat allocations across prefectures is tabulated in Table 1 .

\footnotetext{
${ }^{6}$ For details of the electoral reform, see Christensen (1994), Christensen (1996), Christensen (1998) and Horiuchi and Saito (2003)
} 
The first column tabulates the number of seats assigned for each prefecture before the electoral reform. The second column tabulates the number of seats assigned for the SMDs after the reform. The third column tabulates the estimated number of seats elected by the PR system after the reform. Seats for the PR system are allocated for 11 blocs, so we allocated the seats assigned to each bloc using the weight that is proportional to the number of voters for each prefecture. The fourth column tabulates the total number of seats allocated to each prefecture, which is the sum of the third and fourth columns. A striking finding is that the total number of seats allocated to each prefecture did not change much due to the electoral reform, as indicated by the first and fourth columns. However, the number of seats that are directly elected by voters changed drastically, due to the electoral reform, as evidenced by comparing the first and the second columns.

In our analysis, we focus on the change in the number of seats that are directly elected by politicians' names. This is because those politicians who are elected by their names in their respective electoral districts presumably have a stronger incentive to do pork-barrel politics. In addition, it is widely believed that those Lower House members elected from the SMD have stronger political influence than those who are elected by the PR system. Reflecting this widely shared view, those Lower House members who are elected from the SMD are called Gold members, while those who are elected from the PR system are called Silver members (Asahi Shinbun (2000) and Yomiuri Shinbun (2000)). 
The large change in the number of Lower House members who are directly elected by their names by prefectures presumably created a large variation in the public capital allocation.

\section{Empirical Model}

We estimated the standard prefecture-level Cobb-Douglas production function:

$$
\ln y_{i t}=\beta_{0}+\beta_{1} \ln l_{i t}+\beta_{2} \ln k_{i t}+\beta_{3} \ln g_{i t}+\text { year } \beta_{4}+c_{i}+u_{i t},
$$

where $y_{i t}$ is the gross prefecture domestic product, $l_{i t}$ is the total hours worked defined by person-hour, $k_{i t}$ is the service flow of private capital, and $g_{i t}$ is the service flow from government capital stock, year is the set of year dummy variables, $i$ is the subscript for prefecture, and $t$ is the subscript for year. The error term consists of time-invariant prefecture effects $c_{i}$ and idiosyncratic shock to production $u_{i t}$. If the prefecture effects are not correlated with explanatory variables, (i.e. $E\left(c_{i} \mid l_{i}, k_{i}, g_{i}\right.$, year $)=0$, where $\left.x_{i} \equiv\left[x_{i 1}, x_{i 2}, \ldots, x_{i T}\right]\right)$, and the idiosyncratic error term is strictly exogenous (i.e. $E\left(u_{i t} \mid l_{i}, k_{i}, g_{i}\right.$, year,$\left.\left.c_{i}\right)=0\right)$, then the OLS estimation renders a consistent estimator.

The first assumption, $E\left(c_{i} \mid l_{i}, k_{i}, g_{i}\right.$, year $)=0$, is often refuted in empirical studies because those regions with high output levels tend to have high levels of public capital stock through local government budgetary constraints in the US. This assumption is also likely to be violated in Japan because the central 
government tends to allocate public capital to the permanently stagnating regions in order to attain "balanced growth." Reflecting the difference in the source of the endogeneity of public capital, the OLS estimates are larger than the fixed effects estimates in the US (Holz-Eakin (1994) and Evans and Karras (1994)), but the OLS estimates are smaller than the fixed effects estimates in Japan (Asako, Tsuneki, Fukuda, Teruyama, Tsukamoto, and Sugiura (1994) and Yamano and Ohkawara (2000)).

The second assumption, $E\left(u_{i t} \mid l_{i}, k_{i}, g_{i}, c_{i}\right.$, year $)=0$, may also be violated, although this has not often been pointed out in previous studies. To articulate this point, we assume that the public capital of prefecture $i$ in year $t$ is determined as:

$$
\ln g_{i t}=\delta_{0}+\delta_{1} \ln l_{i t}+\delta_{2} \ln k_{i t}+\delta_{3} \ln y_{i t}+z_{i t} \gamma+\text { year } \beta_{4}+\alpha c_{i}+v_{i t},
$$

where $z$ is the vector of instrumental variables that determines the public capital stock, but does not directly determine the output level after conditioning on $c_{i}$ (i.e. $E\left(u_{i t} \mid l_{i}, k_{i}, z_{i}, c_{i}\right.$, year $\left.)=0\right)$. If $\alpha \neq 0$ then $E\left(c_{i} \mid l_{i}, k_{i}, g_{i}\right.$, year $)=0$ is violated because the unobserved heterogeneity that determines prefectures' output also determines the level of public capital. If $\delta_{3} \neq 0$ then $E\left(u_{i t} \mid l_{i}, k_{i}, g_{i}, c_{i}\right.$, year $)=0$ is violated because the current shock to production affects the current level of public capital. The coefficient $\delta_{3}$ is expected to be positive if the public capital investment in region $i$ at year $t$ is limited by the tax revenue in the same region at the same time. However, if the central government heavily invests in the stagnating regions, $\delta_{3}$ is expected to 
be negative. Under the condition, $\delta_{3} \neq 0$, the productivity of public capital, which is $\beta_{3}$ in (1), is identified only if the instrumental variables exist for public capital; i.e. $\gamma \neq 0$ in (2). The cross-sectional, instrumental variable estimator is consistent if the instrumental variable is exogenous from prefecture heterogeneity, $E\left(c_{i} \mid l_{i}, k_{i}, z_{i}\right.$, year $)=0$, and strictly exogenous from idiosyncratic shock, $E\left(u_{i t} \mid l_{i}, k_{i}, z_{i}, c_{i}\right.$, year $)=0$. The fixed effects instrumental variable estimator is consistent if $E\left(u_{i t} \mid l_{i}, k_{i}, z_{i}, c_{i}\right.$, year $)=0$. This implies that we can obtain a consistent estimator even when $u_{i t}$ and $g_{i t}$ are correlated, as far as $u_{i t}$ and $z_{i t}$ are not correlated conditional on $l_{i}, k_{i}, c_{i}$.

The number of Lower House members who are elected by their names who represent prefecture $i$ in year $t$ is used as the instrumental variable for public capital stock in the corresponding prefecture and year. Because we do not have theoretical guidance of functional form to relate the number of directly elected members and the log of public capital, we tried several specifications and decided to directly include the number of members who are elected by their names as $z_{i t}$ in (2). ${ }^{7}$ The reduction of the total number of directly elected Lower House members in 1996 might have changed the total amount of public capital allocation, but this effect is captured by the year dummies.

\footnotetext{
${ }^{7}$ Note that this functional form issue is not very important because this is an auxiliary regression function to attain an instrumental variable estimation of the equation (1).
} 


\section{Data}

We used the aggregate data of 47 prefectures between 1994 and 1998. These years were chosen in order to include data before and after the electoral reform. The first Lower House election after the electoral reform took place in October 1996, and the last election before the reform took place in June 1993. The effect of reapportionment on public capital allocation presumably started to appear in fiscal year 1997. Thus, we have three years of observations before the reform and two years of observations after the reform. We used gross prefecture product $(y)$ as the measure of prefectural value-added product. These data were taken from Cabinet Office (Each Year). As for person-hour labor input $(l)$, we multiplied the average number of work hours and the number of regular workers taken from Ministry of Labor (Each Year). ${ }^{8}$ The private and public capital stock amounts were taken from Doi (2002). These stock data include the amounts at the end of fiscal year, and the effects of the privatization of the telephone, tobacco, and railway public companies (Dendenkosya, Senbaikosya, and Nihon Kokuyu Tetsudo) and the 1995 Kobe earthquake are adjusted. The number of seats in the Lower House was taken from Ministry of Home Affairs (Each Year), which reported the number of seats for each election year. This is the number of seats elected from the multiple- member districts before the reform and from the single-member districts after the reform. Because Lower House members who occupied

\footnotetext{
${ }^{8}$ Regular workers (Jōyo Rōdosha) include all those who work without fixed-term contracts. This definition includes both part- and full-time workers.
} 
seats in year $t$ exercised their political influence on the budget plan for the fiscal year of $t+1$, the number of seats in year $t-1$ is used to explain the public capital amount if year $t$. As we discuss later, controlling for the capital utilization rate is important, and we used the annual electric power bought by large- scale buyers reported in Federation of Electric Power Companies of Japan (Each Year). Table 2 reports the descriptive statistics of the data.

Figures 1 and 2 implement a "visual" IV estimation. Figure 1 plots the relationship between the log of stock amount of public capital and the lagged number of directly elected members in the House of Representatives, after adjusting for the log of total hours worked, log capital, and year effects. This figure shows that the number of seats in the House of Representatives positively affects the stock amount of public capital. Figure 2 plots the relationship between the regression-adjusted log output and the regressionadjusted lagged number of seats. This figure indicates that the number of seats positively affects the prefectural output. If the number of seats allocated to each prefecture affects production only through public capital provision, then the productivity of public capital is the ratio of the slope coefficient of Figure 2 and the slope coefficient of Figure 1.

\section{Results}

Table 3 reports the regression results on the determination of public capital allocation across prefectures. In addition to the number of seats in the Lower House, the specification includes all the other exogenous explanatory 
variables in the second-stage regression. Column (1) reports the result of the OLS regression, and it indicates that 10 seat increase in the directly elected seats in the Lower House results in about a 20 percent increase in public capital allocation. Column (2) reports the fixed effects result. This result indicates that ten-seat increase in the Lower House increases the public capital allocation by about 3 percent. This huge drop in the coefficient's magnitude implies that the unobserved prefectural heterogeneity that positively affects public capital allocation is negatively correlated with the number of Lower House seats. This is not surprising because a large prefecture, in terms of either area or population, attracts more public capital and has more seats in the Lower House, even after controlling for labor and capital inputs. In both the OLS and fixed effects, the number of seats explains the allocation of public capital across prefectures, and this evidence is consistent with the previous finding by Horiuchi and Saito (2003). This finding assures that having seats in the Lower House works as a good instrument for public capital allocation, in that it affects prefectural production only through this allocation.

Table 4 tabulates the estimation results of the prefectural production function that includes public capital, private capital, and employee-hours as inputs. Column (1) reports the OLS regression result. In this specification, prefecture public capital does not significantly explain prefecture production, but the coefficient for labor is 0.60 and the coefficient for capital is 0.42 , which are standard values in the estimation of the production function. ${ }^{9}$ The coeffi-

\footnotetext{
${ }^{9}$ It should be noted that the estimated coefficient for inputs could be biased if the input
} 
cient for public capital changes significantly once the possible endogeneity of public capital is taken care of by an IV estimation, whose result is reported in Column (2). The result of the IV estimation that uses the lagged number of directly elected seats in the Lower House indicates that a one percent increase in public capital increases the output by 18 percent, but this effect is not precisely estimated, as indicated by the large standard error. The coefficient for labor input was reduced from the OLS estimate of 0.60 to 0.45 because the public capital amount and the labor input are positively correlated, and the downward bias for the public capital coefficient was canceled by the upward bias for the labor coefficient. If we take this change in the coefficient seriously, it implies that the unobserved prefecture production heterogeneity and the stock amount of public capital are negatively correlated. This result is consistent with those of previous studies that have pointed out that public capital is strategically allocated to Japan's poorer prefectures. If only the variation in public capital that is explained by the variation in seat allocation is used for the estimation, the estimate points to public capital's positive contribution to production.

Another strategy to deal with the possible endogeneity of public capital is to use a fixed effects estimation that allows for the correlation of timeconstant prefecture heterogeneity and explanatory variables, including public capital. The result of the estimation appears in Column (3). The estimated amount responds to the regional-level, unobserved technological shock that is not captured by the year dummies. 
coefficient for public capital is 0.15 with a standard error of 0.15 . Although this estimate is not precise, this again suggests that the OLS estimate, which was 0.01 , was downward biased. This significant change in the estimates suggests a negative correlation between the time-constant, unobserved prefecture heterogeneity and public capital. This finding is consistent with the finding in the IV estimate, and this is probably because public capital investment is distributed toward the poorer prefectures. The coefficients for labor and private capital inputs are both insignificant; this is probably because of measurement errors in these inputs, and thus the attenuation bias becomes serious in the fixed effects estimation. The results of the fixed effects IV estimation appears in Column (4). In this estimation, the change in public capital allocation due to the change in the Lower House seat allocation is used to identify the productivity effect of public capital. In this estimation, the coefficient for public capital jumps very significantly, but this estimate is not reliable, as the large standard error indicates. The estimated coefficient for public capital is not precise because the variation in the change in public capital due to the change in the number of seats in the Lower House is not large.

Overall, we take the cross-sectional instrumental variable estimates as our preferable estimate because this estimate resolves the endogeneity issue and the size of coefficients for labor and private capital are sensible. The fixed effects estimates seem to suffer from an attenuation bias due to possible measurement errors in the input variables. Although the coefficient for public 
capital was not precisely estimated in the IV estimation, the result suggests that the OLS estimates are downward biased.

\section{Discussion}

\subsection{Productivity or Keynesian Effect?}

The discussion so far has assumed that public capital contributes to the prefecture production as an input; however, the traditional Keynesian argument claims that public capital investment stimulates the effective demand and increases production through mobilizing the unemployed resources. The pure productivity effect of public capital on production can be estimated by accurately capturing the level of private inputs because the Keynesian effect operates through a change in the utilization of private inputs. Thus, by controlling for the level of private inputs, we can rule out the Keynesian effect. However, as is commonly discussed in macroeconomics, measuring the service flow from capital is very difficult. If the utilization of capital is not appropriately measured, and a high capital utilization is induced by public capital investment, then the Keynesian effect is captured as the productivity of public capital. The above discussion is illustrated by using the following production function, which incorporates the utilization rate of private capital:

$$
\ln y_{i t}=\beta_{0}+\beta_{1} \ln l_{i t}+\beta_{2} \ln \left(a_{i t} k_{i t}\right)+\beta_{3} \ln g_{i t}+\text { year } \beta_{4}+c_{i}+u_{i t},
$$


where $a_{i t}$ is the utilization rate of capital that takes values between 0 and 1 , but this utilization rate is not observed by us. Treating the $a_{i t}$ as a part of the error term, the estimation equation becomes

$$
\ln y_{i t}=\beta_{0}+\beta_{1} \ln l_{i t}+\beta_{2} \ln k_{i t}+\beta_{3} \ln g_{i t}+\text { year } \beta_{4}+\beta_{2} \ln a_{i t}+c_{i}+u_{i t} .
$$

If the increase in $g_{i t}$ is positively correlated with $a_{i t}$ through the Keynesian effect, the OLS estimator of $\beta_{3}$, which attempts to capture the productivity effect of public capital, is upward biased, given $\beta_{2}>0$. To reduce this bias, we use the variation in electricity usage to capture the varying capital utilization rate, as in Burnside, Eichenbaum, and Rebelo (1996). We assume that the utilization rate of capital stock is proportional to electricity usage as:

$$
\ln \left(a_{i t}\right)=\gamma \ln \left(m_{i t}\right)+v_{i t}
$$

where $a_{i t}$ is the utilization rate of capital stock, $m_{i t}$ is electricity usage, and $v_{i t}$ is an error term that is strictly exogenous from all explanatory variables in (4) and $m_{i t}$. By substituting this relationship into (3), we obtain:

$$
\ln y_{i t}=\beta_{0}+\beta_{1} \ln l_{i t}+\beta_{2} \ln k_{i t}+\beta_{3} \ln g_{i t}+\beta_{2} \gamma \ln m_{i t}+y e a r \beta_{4}+c_{i}+v_{i t}+u_{i t} .
$$

This model is estimated by OLS, IV, fixed effects, and IV fixed effects procedures, as in the previous model. The results of the first-stage estimation appear in Columns (3) and (4) in Table 3. The results indicate that the number of seats in the Lower House is the valid instrument, as it enters the regression significantly, even after controlling for electricity usage. The results of the second- stage regression appear in Columns (5) through (8) in 
Table 4. The results of the second-stage estimation did not change significantly. The coefficients for private capital have changed slightly from the results in Columns (1) through (4), but the coefficients for public capital have not changed much at all. This implies that the utilization of electricity is not correlated with public capital stock, and the estimated effect of public capital on production is not through the stimulation of effective demand, as Keynesians typically presume. Overall, the analysis that attempts to control for the capital utilization rate by using electricity usage indicates that an increase in public capital increases production through enhancing productivity rather than stimulating effective demand.

\subsection{The Effect of a Large-scale Earthquake}

The Kansai area was hit by a large-scale earthquake, called the HanshinAwaji earthquake, on January 17, 1995. The Hyogo prefecture suffered most severely from the earthquake. ${ }^{10}$ Although the data used in this study adjust for the damage on private and public capital, if this earthquake had a negative impact on production that was not captured by the reduced amount of input reduction, then the productivity effect of public capital can be underestimated because the Hyogo prefecture received a relatively large amount of public capital investment for its infrastructure recovery. To address this possibility, we implemented the same estimation with a sample that does not include the Hyogo prefecture.

\footnotetext{
${ }^{10}$ See Doi (2002) for the extent of the damage.
} 
The result of the first-stage regression appears in Columns (5) through (8) in Table 3. The result of the estimation does not change drastically from the results that used all of the prefectures as a sample, which are reported in Columns (1) through (4) in the same table. Even after excluding the Hyogo prefecture, the number of directly elected seats in the Lower House did affect the amount of public capital formation.

Given this valid instrument, the estimation of the production function was implemented, treating the public capital amount as an endogenous variable without the Hyogo prefecture. The estimation results of the production function appear in Table 5. The results of the estimation are virtually the same as the results without the Hyogo prefecture that are reported in Table 4. The OLS estimates indicate that the productivity of public capital is near zero. However, once the possible endogeneity of public capital is controlled for by IV or FE methods, the elasticity of public capital on production is about 0.2 , although the effects are not very precisely estimated. The FEIV results indicate the very high productivity of public capital, but the standard errors are too large to make something out of these results. We consider the cross-sectional IV estimates and panel FE estimates as preferable results and infer the elasticity of public capital on production to be about 0.2 .

\section{Conclusion}

This paper has estimated the productivity of public capital using the 1994 electoral reform in Japan as a source of exogenous variation of public capital 
allocation across regions. The estimation of public capital productivity is very difficult because the public capital amount is endogenous. The 1994 electoral reform in Japan drastically increased the political representation of rural area and increased the allocation of public capital to rural area due to pork-barrel politics. We exploited this exogenous variation of public capital to estimate its productivity. The OLS estimates that neglect the endogeneity of public capital are downward biased because public capital is allocated more heavily to stagnating regions. The IV estimates using the number of seats allocated to each prefecture as the instrument indicate that public capital is moderately productive. The estimated elasticity of public capital on production is about 0.2 , although the effects are not precisely estimated. The fixed effects estimation that allows for the correlated heterogeneity with public capital turned out to be imprecise because the effect from the measurement errors in public and private capital was exacerbated in the fixed effects estimation.

Contrary to the widely held belief among the general public and the media that public capital in Japan is not productive, our estimates indicate that public capital is still moderately productive. Public opinion may be subject to the same sort of bias associated with cross-sectional OLS estimators. Because public capital is more heavily allocated to rural areas where economies are stagnant, people may misperceive that public capital is not productive. However, our IV estimates indicated that rural economies might have been even more stagnant if they had not received public capital. Our results cau- 
tion that future policy discussions on public capital provisions should be based on the estimation results that pay extra attention to the endogeneity of public capital allocation.

\section{References}

Ai, C. and S. P. Cassou, 1997, On public capital analysis with state data, Economics Letters, 57(2), 209-212.

Asahi Shinbun, 2000, The Color of Medal (Medaru no iro), News paper article on May 31, 2000, Tokyo-Kanagawa edition.

Asako, K. A. Tsuneki S. Fukuda H. Teruyama T. Tsukamoto and M. Sugiura, 1994, Productivity of governemnt capital and the welfare evaluation of government investment policy (Shakaishihon no seisanryku kouka to koukyou toushi seisaku no keizai kuosei hyouka), Keizaibunseki, 135.

Aschauer, D. A., 1989, Is public expenditure productive?, Journal of Monetary Economics, 23(2), 177-200.

Burnside, A. C. M. S. Eichenbaum and S. T. Rebelo, 1996, Sectoral Solow Residuals, European Economics Review, 40, 861-869.

Cabinet Office, Each Year, Annual Report on Prefecture Accounts. Printing Bureau.

Chandra, A. and E. Thompson, 2000, Does public infrastructure affect eco- 
nomic activity? Evidence from the rural interstate highway system, Regional Science and Urban Economics, 30(4), 457-490.

Christensen, R., 1994, Electroral Reform in Japan: How it was enacted and changes it may bring, Asian Survey, 34(7), 589-605.

— 1996, The New Japanese Election System, Pacific Affairs, 69(1), 49-70.

— , 1998, The Effect of Electoral Reforms on Campaign Practices in Japan: Putting New Wine into Old Bottles, Asian Survey, 38(10), 9861004 .

Doi, T., 2002, Regional Perspective of Japanese Economy and Fiscal Policy (Tiiki kara mita nihon keizai to zaisei seisaku). Mitsubishi Economic Research Institute, Datasets downloadable from: http://www.econ.keio.ac.jp/staff/tdoi/pfdata.html.

Evans, P. and G. Karras, 1994, Are Government Activities Productive? Evidence from a Panel of U.S. States, The Review of Economics and Statistics, $76(1), 1-11$.

Federation of Electric Power Companies of Japan, Each Year, Handbook of Electric Power Industry. Federation of Electric Power Companies of Japan.

Garcia-Mila, T. and T. J. McGuire, 1992, The contribution of publicly provided inputs to States' economies, Regional Science and Urban Economics, $22(2), 229-241$. 
Garcia-Mila, T. T. J. McGuire and R. H. Porter, 1996, The Effect of Public Capital in State-Level Production Functions Reconsidered, The Review of Economics and Statistics, 78(1), 177-180.

Holtz-Eakin, D. and M. Lovely, 1996, Scale economies, returns to variety, and the productivity of public infrastructure, Regional Science and Urban Economics, 26(2), 105-123.

Holz-Eakin, D., 1994, Public sector capital and the productivity puzzle, Review of Economics and Statistics, 76(1), 12-21.

Horiuchi, Y. and J. Saito, 2003, Reapportionment and Redistribution: Consequences of Electoral Reform in Japan, American Journal of Political Science, 47(4), 669-682.

Ishi, H., 1996, Budgets and the budgetary process in Japan, Hitotsubashi Journal of Economics, 37(1), 1-19.

Iwamoto, Y. S. Ouchi S. Takeshita and T. Bessho, 1996, Productivity of public capital and its regional allocation (Shakai Shihon no Seisansei to Kokyo Toshi no Chiiki-kan Haibun), Financial Review, 41, 27-52.

Mera, K., 1973, Regional Producation Functions and Social Overhaed Capital: An Analysis of the Japanese Case, Regional and Urban Economics, 3(2), 157-186.

Meyer, S. A. and S. Naka, 1998, Legislative influences in Japanese budgetary politics, Public Choice, 94(3-4), 367-383. 
— 1999, The Determinants of Japanese Lacal-Benefit Seeking, Contemporary Economic Policy, 17(1), 87-96.

Ministry of Home Affairs, Each Year, Survey of the results of the general election for the House of Representatives and the national review of the judges of the Supreme Court. Election Department, Local Administration Bureau.

Ministry of Labor, Each Year, Monthly Labor Survey. Printing Bureau.

Mitsui, K. and K. Ohta, 1995, Productivity of public capital and public finance (Shakai Shihon no Setsansei to Kouteki Kinyu). Nihon Hyoronsha.

Munnell, A., 1990, Why has producitivty growth declined? Productivity and public investment, New England Economic Review, pp. 3-22.

Okuno, N., 1988, Public Economics (Kōkyō Keizai). Tōyō Keizai.

Okuno, N. A. Yakita and T. Yagi (eds.)1994, Public Capital and Economic Development. Nagoya University Press.

The Economic Planning Agency, 1997, White paper on economic activity of Japan (Keizai Hakusho). Printing bureau, Ministry of Finance.

Yamano, N. and T. Ohkawara, 2000, The Regional Allocation of Public Investment: Efficiency or Equity, Journal of Regional Science, 40(2), 205229. 
Yomiuri Shinbun, 2000, Gold, Silver, Bronze House Members (Kin, Gin, Dō Giin), News paper article on June 1, 2000, Tokyo edition.

Yoshino, N. and Y. Yoshida, 1988, Emprical Study on the regional allocation of public capital, ESP. 
Table 1: Number of seats in the House of Representative before and after the 1994 Electoral Reform

The first election after the reform took place in October 1996.

\begin{tabular}{|c|c|c|c|c|}
\hline Period & $\begin{array}{c}\text { Before the Reform } \\
1995\end{array}$ & Af & $\begin{array}{l}\text { er the Reform } \\
1996\end{array}$ & \\
\hline $\begin{array}{l}\text { Electoral } \\
\text { System }\end{array}$ & $\begin{array}{c}\text { Single } \\
\text { non-transferable vote } \\
\text { system with } \\
\text { multi-member district. } \\
(\text { Chusenkyo- } k u)\end{array}$ & $\begin{array}{c}\text { Single-member } \\
\text { district (SMD) } \\
\text { plurality rule } \\
(\text { Shosenkyo-ku) }\end{array}$ & $\begin{array}{c}\text { Proportionally } \\
\text { Representative } \\
\text { (PR) System } \\
\text { (Estimates) } \\
\text { (Hirei Daihyo) }\end{array}$ & Total \\
\hline \multicolumn{5}{|l|}{ Prefecture } \\
\hline Hokkaido & 23 & 13 & 8 & 21 \\
\hline Aomori & 7 & 4 & 2 & 6 \\
\hline Iwate & 7 & 4 & 2 & 6 \\
\hline Miyagi & 8 & 6 & 3 & 9 \\
\hline Akita & 7 & 3 & 2 & 5 \\
\hline Yamagata & 7 & 4 & 2 & 6 \\
\hline Fukushima & 12 & 5 & 3 & 8 \\
\hline Ibaragi & 12 & 7 & 3 & 10 \\
\hline Tochigi & 10 & 5 & 6 & 11 \\
\hline Gunma & 10 & 5 & 6 & 11 \\
\hline Saitama & 20 & 14 & 6 & 20 \\
\hline Chiba & 19 & 12 & 5 & 17 \\
\hline Tokyo & 43 & 25 & 17 & 42 \\
\hline Kanagawa & 22 & 17 & 7 & 24 \\
\hline Niigata & 13 & 6 & 5 & 11 \\
\hline Toyama & 6 & 3 & 2 & 5 \\
\hline Ishikawa & 5 & 3 & 2 & 5 \\
\hline Fukui & 4 & 3 & 2 & 5 \\
\hline Yamanashi & 5 & 3 & 2 & 5 \\
\hline Nagano & 12 & 5 & 6 & 11 \\
\hline Gifu & 9 & 5 & 3 & 8 \\
\hline Shizuoka & 14 & 9 & 5 & 14 \\
\hline Aichi & 22 & 15 & 10 & 25 \\
\hline Mie & 8 & 5 & 3 & 8 \\
\hline
\end{tabular}




\begin{tabular}{|c|c|c|c|c|}
\hline Shiga & 5 & 3 & 2 & 5 \\
\hline Kyoto & 10 & 6 & 4 & 10 \\
\hline Osaka & 28 & 19 & 13 & 32 \\
\hline Hyogo & 19 & 12 & 8 & 20 \\
\hline Nara & 5 & 4 & 2 & 6 \\
\hline Wakayama & 5 & 3 & 2 & 5 \\
\hline Tottori & 4 & 2 & 1 & 3 \\
\hline Shimane & 5 & 3 & 1 & 4 \\
\hline Okayama & 10 & 5 & 3 & 8 \\
\hline Hiroshima & 13 & 7 & 4 & 11 \\
\hline Yamaguchi & 9 & 4 & 2 & 6 \\
\hline Tokushima & 5 & 3 & 1 & 4 \\
\hline Kagawa & 6 & 3 & 2 & 5 \\
\hline Ehime & 9 & 4 & 2 & 6 \\
\hline Kochi & 5 & 3 & 1 & 4 \\
\hline Fukuoka & 20 & 11 & 7 & 18 \\
\hline Saga & 5 & 3 & 1 & 4 \\
\hline Nagasaki & 9 & 4 & 2 & 6 \\
\hline Kumamoto & 9 & 5 & 3 & 8 \\
\hline Oita & 6 & 4 & 2 & 6 \\
\hline Miyazaki & 5 & 3 & 2 & 5 \\
\hline Kagoshima & 9 & 5 & 2 & 7 \\
\hline Okinawa & 5 & 3 & 2 & 5 \\
\hline
\end{tabular}

Note: After the electoral reform, 200 members of the Lower House were elected by the proportionally representative system from 11 blocks. We allocated these seats to prefectures proportionally, to the number of voters in each prefecture that consists of a block. Because of rounding, the total number of PR seats does not add up to 200. 
Table 2: Descriptive Statistics

Sample: All 47 prefectures between 1994 and 1998.

\begin{tabular}{lccccc}
\hline & Mean & $\begin{array}{c}\text { Standard } \\
\text { Deviation }\end{array}$ & Minimum & Maximum \\
& & & \\
\hline $\begin{array}{l}\text { Output (Million Yen) } \\
\text { Annual Employee Hours (Million }\end{array}$ & 10182.9 & 13011.7 & 1928.6 & 80600.9 \\
Hours) & 1571.52 & 1962.32 & 327.7 & 12219.9 \\
Private Capital Stock (Million Yen) & 19474.2 & 24243.5 & 3164.5 & 159204.0 \\
Public Capital Stock (Million Yen) & 14353.2 & 12283.9 & 4221.7 & 68100.0 \\
Electric Power (Million KWh) & 5498.9 & 5287.9 & 603.0 & 25876.0 \\
Seats in Lower House Directly Elected & 8.2 & 6.5 & 2.0 & 43.0 \\
\hline
\end{tabular}

Note: $\mathrm{N}=235$. Output and public capital stock are denominated in the 1990 price. Capital stock is denominated in the 1990 price. Employment indicates the number of regular workers, including both full- and part-time workers. 


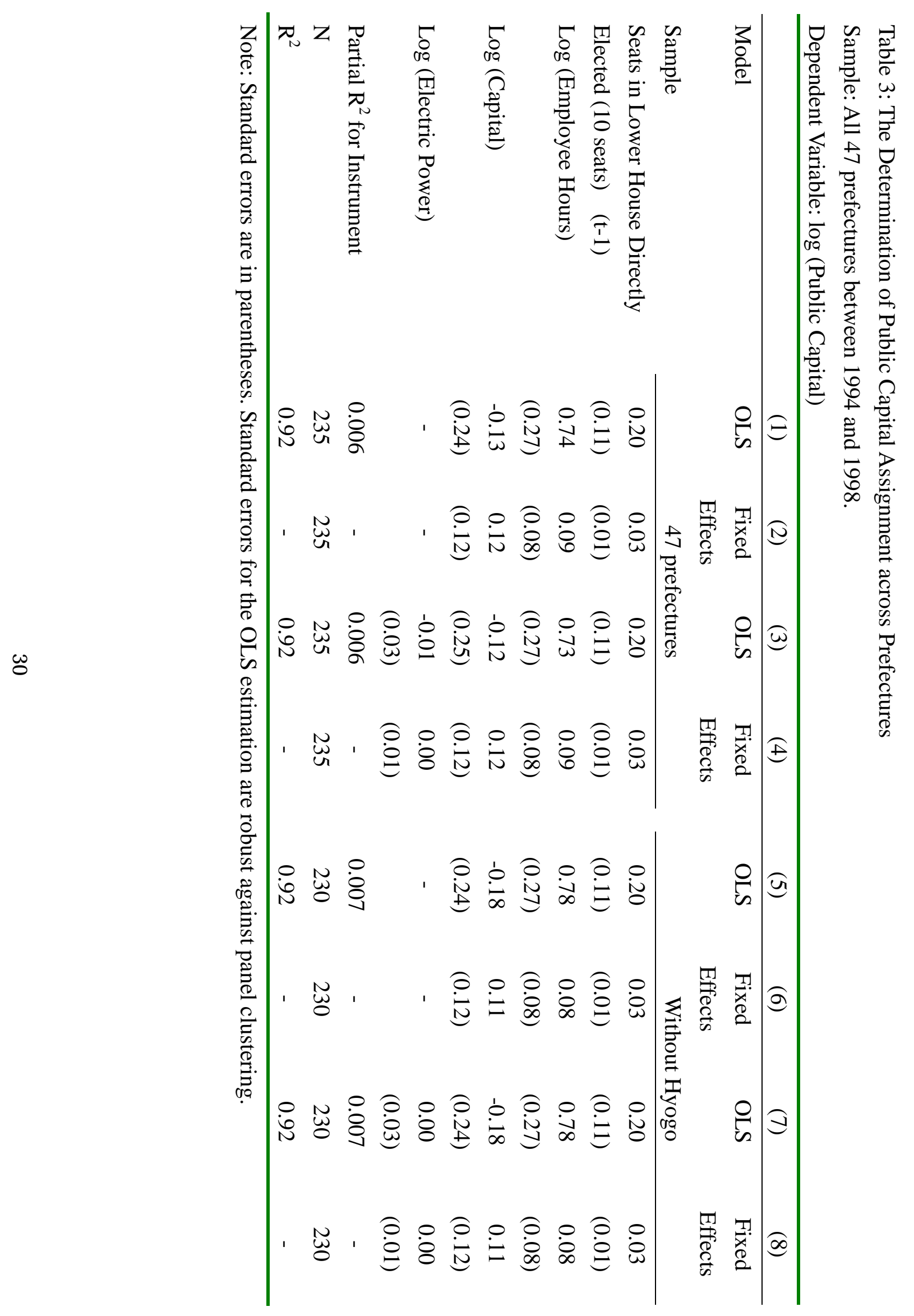




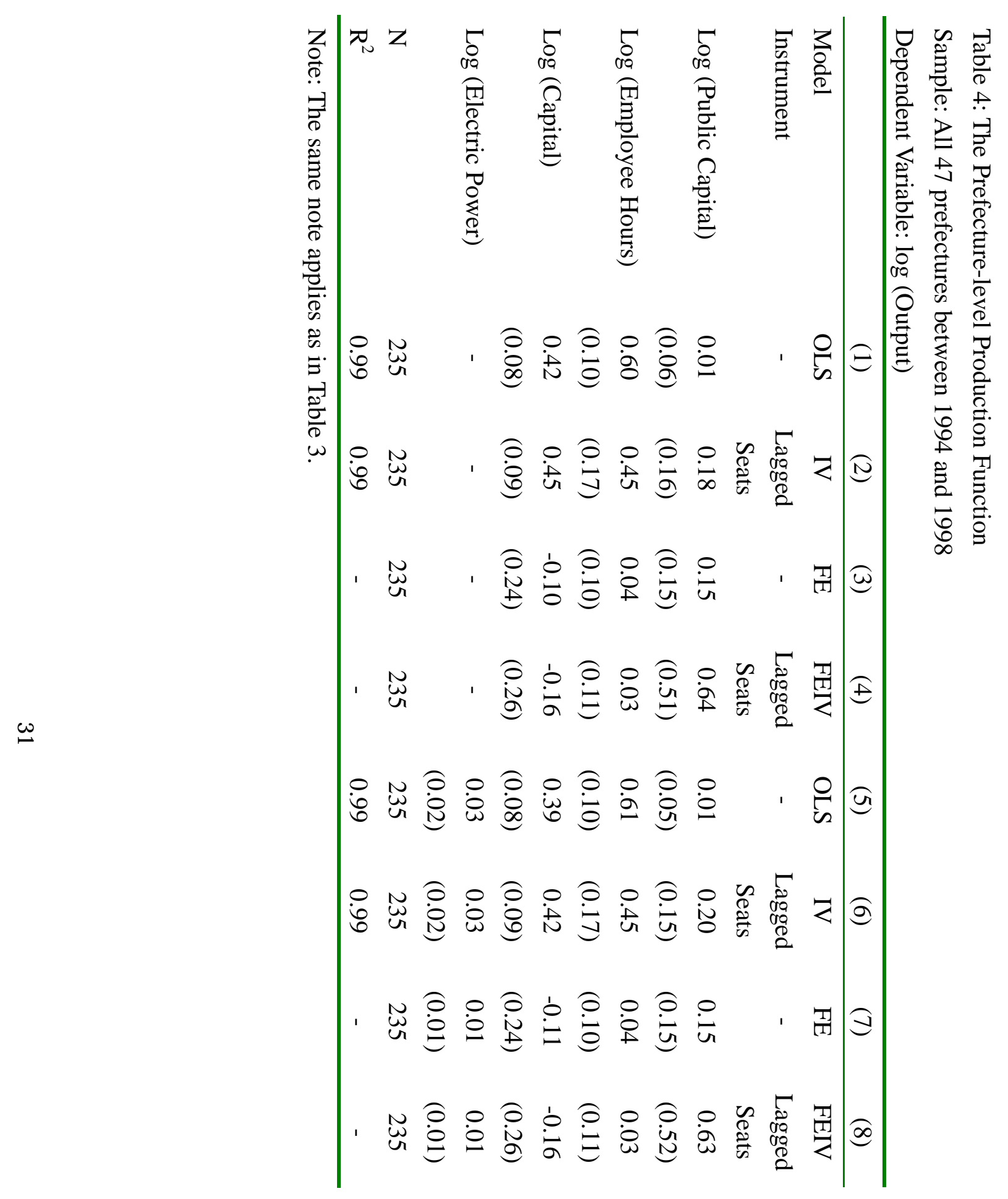




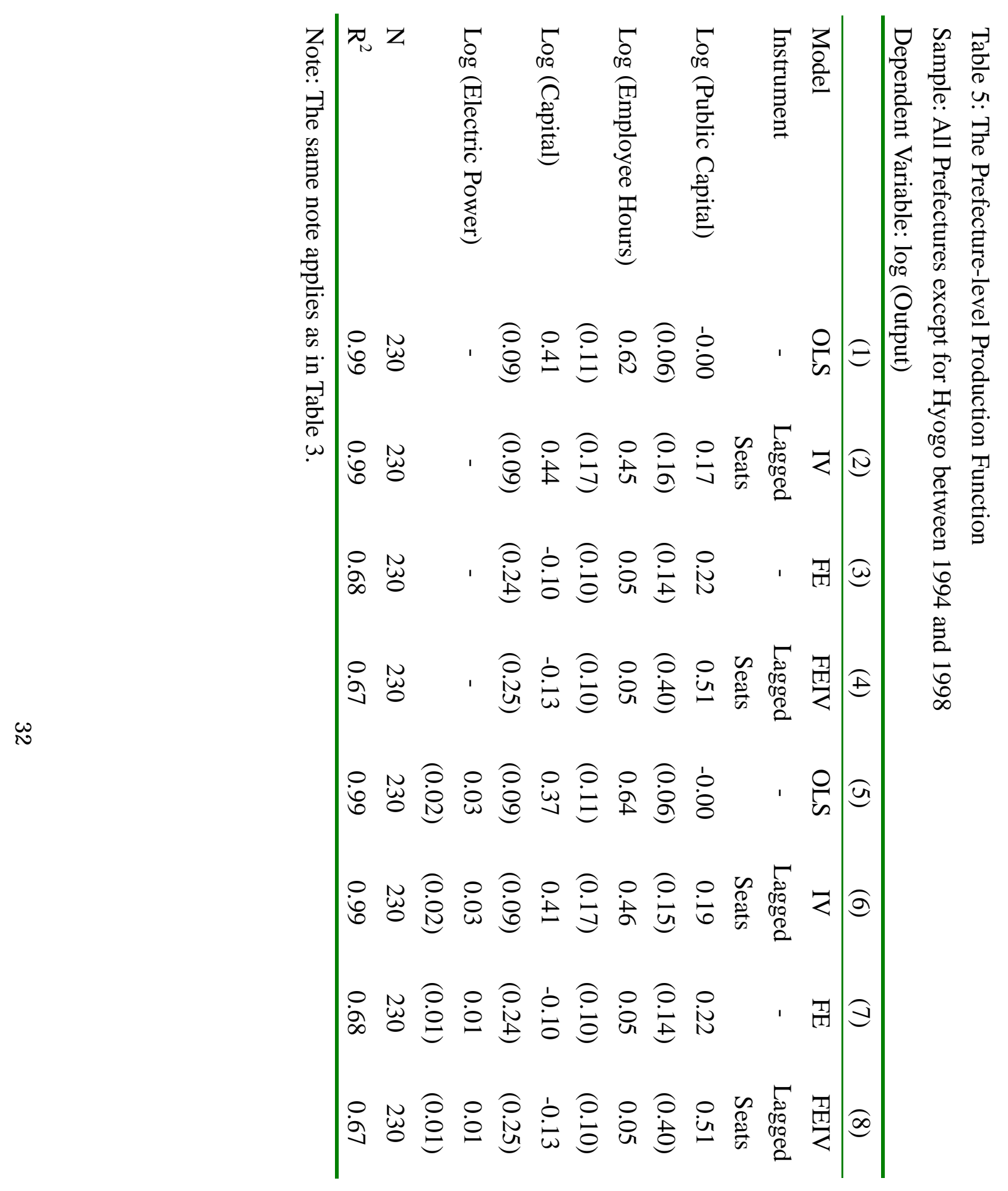


Figure 1: Log (Public Capital) and Lagged Number of Seats

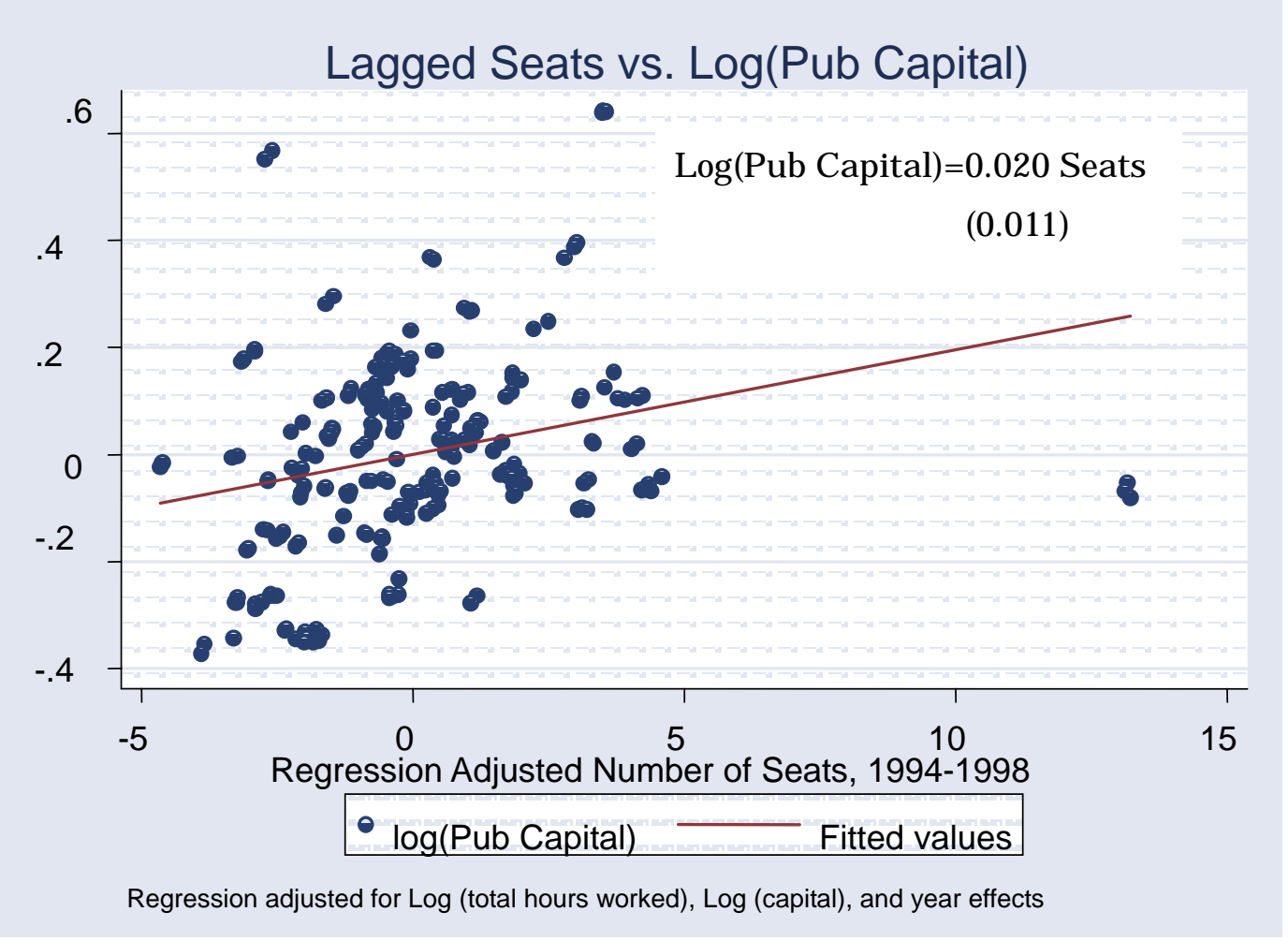

Figure 2: Log (Output) and Lagged Number of Seats

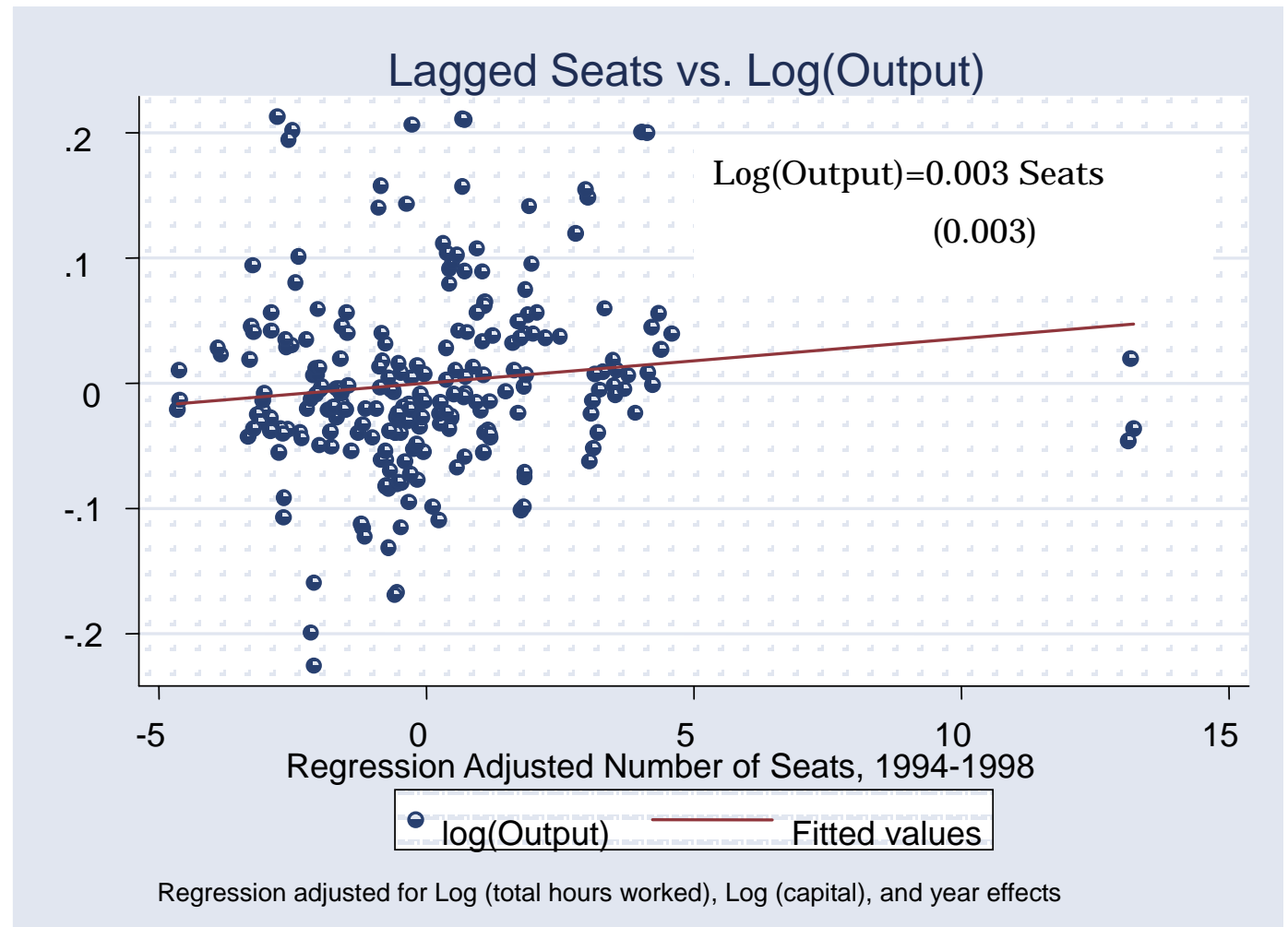

